\title{
Sindicabilidade Judicial das Políticas Públicas
}

\section{Cynthia Candomil Dandolini}

\section{INTRODUÇÃo}

O tema Que será tratado na presente pesquisa é de extrema relevância para a comunidade científica e aplicadores do Direito. Discutir-se-á a efetivação dos direitos e garantias fundamentais.

Se de um lado a Administração Pública pode agir com discricionariedade na implantação de políticas públicas que visem à concretização dos direitos fundamentais, também é verdade Que ela está vinculada a determinadas diretrizes. Tais diretrizes devem ser aquelas traçadas pelo Constituinte e mesmo pelo legislador infraconstitucional, Quando as normas criadas por este estiverem em harmonia com a Constituição Federal.

Trata-se de tema instigante, capaz de trazer à tona antigas discussōes. Dentre elas, a crítica à chamada "Politização do Poder Judiciário" e mesmo à rigidez da chamada "Teoria da Separação dos Poderes".

Merecerá maior ênfase, no entanto, o estudo das denominadas "Políticas Públicas". Ou seja, o estudo de metas coletivas que direcionam a atividade do Estado, objetivando o interesse público,

Será abordado o atual estágio de desenvolvimento da cultura jurídica e a missão do Judiciário como Poder inserido em um Estado Social de Direito. Por essa razão, será demonstrada a imprescindibilidade da reorganização estatal em função de finalidades coletivas.

Dentre os princípios que constituem o Estado de Direito, Quais sejam, a legalidade, a igualdade e a justicialidade, será dada maior ênfase a este último. Isto possibilitará trazer à baila a Questão da exigibilidade de implantação de políticas públicas pelo Poder Judiciário.

Serão discutidos os limites a Que está adsirito o Poder Judiciário na implantação de políticas públicas. Para isso, será examinada a separação de poderes como premissa do Estado de Direito. 
Serão analisados os caracteres marcantes do Estado Liberal em contrapartida ao Estado Social. Dessa forma o leitor poderá vislumbrar as diretrizes postas pela Constituição sob a ótica da justiça social e do indivíduo inserido na coletividade.

Pretender-se-á com a presente pesquisa trazer à luz, para Que sejam refletidas, algumas das Questões mais instigantes do Direito Constitucional da atualidade. Dentre elas, o papel do Poder Judiciário frente à implementação de políticas públicas.

\section{O ESTADO SOCIAL DE DIREITO}

\subsection{O Estado de Direito e o Atual Papel do Judiciário na Sociedade Brasileira}

A Constituição Federal de 1988 representou um marco na redefinição do papel das instituições relacionadas à atividade jurisdicional. Neste novo cenário ampliou-se o espaço de atuaçáo dos intérpretes e agentes políticos Que passaram a desempenhar seu papel frente a uma "função social do Direito".

Erigida sob o manto de um Estado Democrático de Direito (art. $\mathrm{I}^{\circ}, \mathrm{CF} / 88$ ), a Constituição Federal de 1988 pauta-se nos princípios da igualdade, legalidade e judicialidade. ${ }^{2}$ Este último, o Qual merecerá aQui especial relevo, pressupõe a separação de poderes, tema Que será tratado mais adiante.

No Estado de Direito, o Direito abandona sua função de mero regulador das atividades entre os homens para tornar-se instrumento de implantação de políticas públicas garantidas pela Constituição. É a Constituição Que limita o poder e, portanto, nenhum órgão, por maior Que seja a sua hierar Quia detém Qual Quer poder Que não o Que advém da própria Constituição. Esse Estado, constituído para garantir os direitos, procede por melo de leis, gerais, impessoais e iguais para todos, às Quais se submetem seus próprios órgãos. ${ }^{3}$

O princípio da judicialidade ${ }^{4}$, ou seja, Que todo litígio deva ser submetido a um juiz, consagrou-se e arraigou-se no Direito Inglês da "common law". Neste sistema, havia uma sucessão de decisões judiciais, no Qual a jurisdição e a legiferação confundiam-se nos mesmos órgãos. Foi tendo em vista este contexto Que Montesquieu, inclusive, dedicou sua obra "Do Espírito das Leis" especialmente à Constituição da Inglaterra no Que se refere à "Separação de Podres".

ENGELMANN, Fabiano. A "judicialização da política" e a "politização do ludiciário" no Brasil - Notas para uma abordagem sociológica. Revista da Faculdade de Direito da Universidade Federal do Rio Grande do Sul, Porto Alegre, vol. 22, p. 193-202, set. 2002.

2 FERREIRA FILHO. Manoel Gonçalves. O Estado de Direito e Constituição. 3. ed. São Paulo: Saraiva, 2004. p. 23.

3 FERREIRA FILHO, op. cit., p. 4.

4 Conforme será referido no item 2.3.

5 FERREIRA FILHO, op. cit., p. 36. 
No Estado de Direito, o Judiciário está comprometido com a efetividade da Constituição, não podendo, no entanto, ultrapassar certos limites, sob pena de violar os postulados do próprio Estado de Direito. Cabe assim indagar: até onde a Constituição Federal de 1988 garante efetividade aos direitos sociais?

Significa dizer que ao Judiciário é possível determinar a implantação e dar efetividade às políticas públicas previstas na ordem constitucional. São elas desde já exigíveis judicialmente, cabendo ao juiz verificar, na hipótese de omissão do Poder Público, se o direito exigido é compatível com o Que seria razoável de se esperar do Poder Público. ${ }^{6}$ Mais ainda, ao ludiciário é possivel exigir do Poder Público Que implante políticas públicas, ainda Que, progressivamente, para atender aos interesses da sociedade brasileira, Quando, apesar de previstas no texto constitucional, houver indubitável escassez de recursos. ${ }^{7}$

Não se olvide Que para garantir efetividade aos direitos assegurados pela Constituição Federal são necessárias condições materiais propícias ${ }^{8}$ para por em prática os programas de direitos básicos formalmente postos na Constituição Federal. Eis o grande dilema do Estado Social de Direito: compatibilizar a amplitude dos direitos sociais postos na Constituição Federal com a precariedade dos recursos estatais disponíveis.

Há, portanto, uma verdadeira redefinição do papel a ser desempenhado pelo Poder ludiciário na sociedade brasileira face à nova ordem constitucional estabelecida a partir de 1988. Está o ludiciário comprometido com a efetividade das políticas públicas, criando uma nova dogmática constitucional, na Qual as mesmas não representem meras promessas e, sim, possuam um mínimo de força normativa.

\subsection{O Estado Social versus o Estado Liberal - Novas Atribuiçóes}

O Estado Liberal foi marcado pelo dualismo entre Sociedade e Estado. ' Dessa forma, contra eventuais acometidas do Estado contra a liberdade e a propriedade, nascem os direitos fundamentais, de linhagem individualista. ${ }^{10}$

- CLÈVE, Clémerson Merlin. A eficácia dos direitos fundamentais sociais. Boletim Científico ESMPU, Brasília, ano 2, n. 8, p. 151//61, jul./set. 2003.

7 CLÈVE, op. cit., p. 15]-161.

8 Conforme será referido no item 2.3.

9 Conforme CANOTILHO, José Joaquim Gomes. Direito Constitucional. 5. ed. Coimbra: Almedina, 1992. p. 77, o dualismo Estado-Sociedade significa Que: "A força normativa da Constituição traduz-se na sua pretensão de regular juridicamente o estatuto organizatório dos órgãos do Estado separado da sociedade (dualismo Estado-Sociedade)".

10 WEICHERT, Marton Alberto. Saúde e Federaçăo na Constituição Brasileira. São Paulo: Lumen Juris, 2004. 
Dentro da Sociedade Liberal, os direitos fundamentais eram, essencialmente, os direitos da liberdade, traçados por uma ótica individualista, pertinente à liberdade pessoal, à propriedade, à inviolabilidade de domicílio e da correspondência, às liberdades de opinião, assembléia, reuniāo, crença religiosa, etc. ${ }^{11}$ Após o término da Primeira Grande Guerra Mundial, o liberalismo cede lugar ao Estado Social, pondo fim ao Estado abstencionista. Ao invés de um Estado passivo em Que a condução da sociedade e da economia flui, naturalmente, como ocorre no Estado Liberal, no Estado Social busca-se harmonia através de planejamento por parte do Estado. O Estado torna-se provedor das necessidades dos indivíduos. Dá-se ao Estado um conteúdo econômico e social, servindo a política de instrumento para refazer o mundo ${ }^{12} \mathrm{O}$ Estado passa a ter como meta corrigir as desigualdades sociais. Há uma interaçāo entre Estado e Sociedade. Este é o Estado Social. ${ }^{13}$

No Estado Social a missão primordial passa a ser a garantia das condiçöes básicas da existência, buscando, assim, realizar a justiça material, compatibilizando liberdade e igualdade. ${ }^{14}$ Afasta-se a linha Que separa o Estado da Sociedade. O Estado torna-se onipresente, devendo realizar prestações de modo concreto, portando-se como administrador diligente e enérgico. É por isso, predominantemente, administrativo, ${ }^{15}$

Importante assinalar Que, na estrutura do Estado Dirigente ${ }^{i 6}$, a lei perde a sua majestade de expressão da soberania popular e torna-se mero instrumento de governo. A grande maioria das leis insere-se, hoje, no Quadro das políticas governamentais, deixando de lado a função de declarar direitos e deveres em situações jurídicas permanentes, para assumir a função de solucionar Questóes de conjuntura, direcionar atividades privadas e regular procedimentos na ceara administrativa. ${ }^{17}$

"WEICHERT, op. cit.

12 DOBROWOLSKI, Sívio. A expansão do poder no estado social - Aspectos - Idéias para contê-la. Revista Forense, Rio de laneiro, ano 82, v. 295, p. 145-154, jul./ago./set. 1986.

13 DOBROWOLSKI, op. cit., p.145.

${ }^{14}$ DOBROWOLSKI, op. cit., p. 147.

is DOBROWOLSKl, op. cit., p. 147.

${ }^{16}$ Conforme CANOTILHO, José loaquim Gomes. Direito Constitucional. 5. ed. Coimbra: Almedina. 1992. p. 13, ao dissertar sobre a sua idéia de Constituição, a da modernidade, por ele antes denominada de "Constituição Dirigente": "Trata-se de um documento escrito concebido como produto da razão Que organiza o mundo, iluminando-o e iluminando-se a si mesma, pretendia-se também converter a lei escrita (= lei constitucional) em instrumento jurídico de constituiçăo de sociedade. É conjunto normativo ativo e finalístico, regulador da sociedade." lá para a pós-modernidade, continua Canotiłho (p. 14): " (...) a Constituição deixa de inserir-se no processo histórico de emancipação da sociedade (Quer como "texto" de garantias individuais e arranjos organizatórios de tipo liberal, Quer como "programa dirigente" de carriz marxizante). Concebe a Constituição como "urn estatuto reflexivo que através de certos procedimentos, do apelo a auto-regulações de sugestóes no sentido da evoluçăo político-social permite a existência de uma pluralidade de opções políticas, a compatibilização dos dissensos, a possibilidade de vários jogos políticos, a garantia da mudança através da construção de rupturas".

7 COMPARATO. Fábio Konder. Ensaio sobre o juízo de constitucionalidade de políticas públicas. Revista dos Tribunais, São Paulo, v. 86, n. 737, p. 11-22, mar. 1997. 
Com a ampliação das atribuiçōes inerentes ao Estado Social, surge um gigante administrador levando-nos a um novo desafio, Qual seja, o de identificar, na medida do possível, os limites dessa nova visão de Estado. Nessa esteira, passa o Poder Judiciário a desempenhar seu papel de controle em relação a esses limites. ${ }^{18}$

Entretanto, diferentemente do Que ocorreu com a Constituição Portuguesa, Que em seu texto original previu em seu art. $2^{\circ}$ o objetivo de assegurar a transição para o socialismo, a atual Constituição brasileira não possui orientação socializante de matriz Marxista. Não se deve confundir, pois, o Estado Social com o Estado Socialista.

A Constituição do Estado de Direito Social baseia-se nos seguintes princípios: a) princípio do compromisso conformador ou constitutivo, cabendo ao Estado intervir na sociedade para melhor assegurar as formas de existência social; b) princípio da democratização da sociedade Que obriga a intervençôes de caráter econômico e social tendentes à prossecução do princípio da igualdade; c) princípios do Estado de Direito Formal racionalizadores e limitadores das medidas intervencionistas (princípio da liberdade). ${ }^{20}$ já a Constituição do Estado Socialista, está calcada nos seguintes princípios: a) Caráter classista do Estado; b) princípio do Estado máximo, que exige o controle e propriedade, pelos Poderes Públicos, dos principais meios de produção; c) princípio da não-neutralidade, impondo-se ao Estado tarefas de transformação econômica, social e cultural. ${ }^{21}$

Não basta, porém, Que uma Constituição tipifique um Estado Social. Isto por si só não resolve a questão da implementação dos direitos sociais. Isto porque no Estado Social já não se mostra suficiente que a Constituição estipule objetivos e deveres do Estado, mas, muito mais que isso, é necessário que existam ações ativas, positivas do Poder Público, aí incluídas as políticas públicas, a fim de darem eficácia aos direitos sociais proclamados na Constituiçã̇o. ${ }^{22}$

18 CAPPELLETTI, Mauro. Constitucionalismo moderno e o papel do Poder ludiciário na sociedade contemporânea. Revista de Processo, São Paulo, v. 15, n. 60, p. 110-117, out./dez. 1990.

19 Conforme FERREIRA FILHO, Manoel Gonçalves. Estado de Direito e Constituição. São Paula: Saraiva, 2004, p. 65-69: "A expressăo presente no art. $2^{\circ}$ da Constituição Portuguesa, de acordo com a primeira revisão feita en 1982, Qual seja, "Estado de Diłeito Democrático" baseia-se em um Estado que objețva assegurar a transição para o socialismo por meio da democracia econômica, social e cultural e o aprofundamento da democracia participativa. As diretrizes fixadas na Constituição Portuguesa teriam orientação socializante, de inspiração Marxista e o Poder Político estaria preso à realização do socialismo. Essa idéía, no entanto, está muito distante da idéia de Direito clássico, ainda remanescente nas democracias de derivação liberal. A transição para o socialismo estava expressamente prevista no art. $2^{\circ}$ da Constituição Portuguesa de 1976. Que procedimento de revisão foi eliminada do texto fundanental português. "Art. $2^{\circ}$ : A Repúbłica Portuguesa é um Estado de direito democrático, baseado na soberania popular, no respeito e na garantia dos direitos c liberdades fundamentais e no pluralismo de expressão e organização política democráticas, Que tem por objetivo assegurar a transição para o socialismo mediante a realizaçăo da democracia cconômica, social e cultural, e o aprofundamento da democracia participativa"."

${ }^{20}$ CANOTLLHO, op. cit., p. 77.

${ }^{21}$ CANOTILHO, op. cit., p. 78.

${ }^{22}$ WEICHERT, op. cit. 
Não há no atual estágio do Estado Social espaço para Qualquer doutrina Que se proponha a recusar força normativa aos preceitos Que fixam deveres positivos ao Estado e à sociedade no cumprimento dos objetivos sociais. ${ }^{23}$ As ordens econômica e social inseridas na Constituição Federal de 1988 apontam para um Estado Social24 ${ }^{24}$ o Qual persegue a Justiça Social, ou seja, aquela dirigida à consecução do bem comum, conforme se extrai dos arts. 170, "caput" e 193. ${ }^{25}$ O direito à saúde ${ }^{26}$, por exemplo, previsto no art. $196^{27} \mathrm{da}$ Constituição Federal de 1988, é um típico direito de justiça social.

A Constituição Federal de 1988, por exemplo, ao referir a promoção, proteção e recuperação da saúde, adota um conceito amplo de saúde não apenas referente a um corpo e a uma mente sem doenças, como também a condiçóes de vida e a um meio ambiente equilibrado. ${ }^{28}$ Nesse sentido, basta que se faça uma leitura do art. $3^{\circ}$ da Lei n. 8.080/90, o Qual dispõe que: "A saúde tem como fatores determinantes e condicionantes, entre outros, a alimentação, a moradia, o saneamento básico, o mejo ambiente, o trabalho, a renda, a educação, o transporte, o lazer e o acesso aos bens e serviços essenciais; os níveis de saúde da população expressam a organização social e econômica do País".

Assim, mais do que um conteúdo meramente semântico, o referido artigo $3^{\circ}$ da Lei n. 8.080/90 vincula a atividade legiferante e administrativa da União, dos Estados, Distrito Federal e Municípios. Esses, por sua vez, deverão orientar suas políticas sociais e econômicas na mesma direção da proteção ao direito à saúde. ${ }^{29} \mathrm{O}$ direito à saúde, portanto, engloba a exigibilidade de políticas públicas econômicas e sociais. Tais políticas, no entanto, devem observar para Que não haja retrocesso na promoção, proteção e recuperação da saúde, buscando acelerar a consecução de suas finalidades. ${ }^{30}$

${ }^{23}$ WEICHERT, op, cit.

${ }^{24}$ Conforme BONAVIDES, Paulo. Curso de Direito Constitucional. 5. ed. São Paulo: Malheiros, 1994. p. 336: "A Constituição de 1988 é basicamente uma constituição do Estado Social. A Constituição do Estado liberal diferencia-se da Constituição do Estado Social. A primeira é uma constituição anti-governo, a segunda uma constituiçăo refratária ao individualismo no Direito e ao absolutismo no Poder". E segue o autor (p. 338): "Em substituição ao clássico Estado de Direito, surgiram o Estado Social e o Estado Socialista. o Estado social brasileiro não apenas concede direitos sociais básicos, mas os garante, a fím de torná-los cfetivos".

25 "Art. 170, "caput", A ordem econômica, fundada na valorizaçäo do trabalho humano e na livre iniciativa, fem por lim assegurar a todos existência digna, conforme os ditames da justiça social, observados os seguintes princípios:." "Art. 193: A ordem social tem como base o primado do trabaho, e como objetivo o bem-estar e a justiça sociais."

26 Conforme será referido no item 2.3.

27 "Art. 196: A saúde é direito de todos e dever do Estado, garantido mediante políticas sociais e econômicas Que visem à redução do risco de doença e de outros agravos e ao acesso universal e igualitário às açöes $\mathrm{e}$ serviços para sua promoção, proteçăo e recuperação."

${ }^{28}$ WEICHERT, op. cit.

29 WEICHERT, op. cit.

${ }^{30}$ WEICHERT, op. cit. 


\section{POLÍtICAS PÚBLICAS}

\subsection{A Separação de Poderes e o Controle Judicial do Agir do Estado}

A divisão de poderes, mais do Que uma técnica de redução e limitação dos poderes, decorrente de sua distribuição por diferentes forças políticas e sociais, constitui uma técnica de defesa da liberdade política do cidadão no Estado. Trata-se de poderes que se delimitam, colaboram e se controlam reciprocamente. ${ }^{31}$

Havia um abuso dos órgãos jurisdicionais, uma verdadeira intromissão na tomada das decisōes políticas daí porque segundo a teoria da Separação de Poderes, de Montesquieu ${ }^{32}$, o Poder Judiciário deveria permanecer nulo como poder, devendo limitar-se à mecânica, inanimada aplicação da lei. Faltava, portanto, um poder capaz de assegurar o respeito à Constituição por parte do grupo político. ${ }^{33}$

Na França pré-revolucionária, por exemplo, os "parlamentos" constituíam um último reduto defensor das reivindicações dos privilegiados. Órgãos jurisdicionais semiprofissionalizados, os "parlamentos" eram, ou pelo menos pretendiam ser, não apenas tribunais, mas também órgãos legislativos. Reclamavam face ao soberano o poder e o dever de examinar todas as leis e decretos que Ihe fossem submetidos, atestando da sua conformidade com as leis fundamentais do reino. Esta teoria da "heureuse impuissance" do monarca legislador impedia-o de decretar aquilo que hoje chamaríamos de leis inconstitucionais. Mas apesar dessa invocação de limites ao poder real, o monarca, através da "demande en cassation", sempre conseguiria lançar mão de um meio de garantir a supremacia da sua vontade. Através desse pedido, a decisão de um "parlamento" podia ser desafiada e trazida perante o "Conseil des Parties", dotado, por sua vez, de poderes de anulação da decisão precedentemente tomada, com base na violação de ordenanças reais. ${ }^{34}$

Apesar da existência deste check, os "parlamentaires" adQuiriram a reputação de interferirem com demasiada freQüência nas atividades dos outros órgãos. Por essa razão foram acusados de abuso arbitrário do poder, o Que, em larga medida, contribuiu para transformar os juízes em meros aplicadores da letra da lei a casos individuais, de forma puramente mecânica e de modo algum criativa, o Que ia ao encontro da teoria da Separação de Poderes de Montesquieu. ${ }^{35}$

31 QUEIROZ, Cristina M. M.. Os actos políticos no Estado de Direito - O problema do controle jurídico do poder. Colmbra: Livraria Amedina, 1990.

32 MONTESQuIEU. Do espírito das leis. Martin Claret: São Paulo, 2002, Livro XI, Capítulo VI, ps. I65/ 175.

${ }^{39}$ CAPPELLETTI, Mauro. Constitucionatismo moderno e o papel do poder judiciário na sociedade contemporânea. Revista de Processo, Săo Paulo, v. 15, n. 60, p. II0-117, out./dez. 1990.

31 QUEIROZ, op. cit.

35 QUEJROZ, op. cit. 
O Constitucionalismo Moderno, Que hoje tem tomado proporçōes e tendências universais, abandona a rígida separação de poderes (separation des pouvoirs) aliada à não interferência e supremacia incontrolada do poder político. Dessa forma, visa a afirmar a idéia de um recíproco controle e equilíbrio dos poderes. ${ }^{36}$

A Constituição Federal de 1988 encontra-se na vanguarda de uma tendência evolutiva contemporânea, Qual seja, abandona a rígida separação de poderes para dar lugar a uma "sharing of powers", desaparecendo, portanto, um poder político ilimitado e imune a QualQuer forma de controle. ${ }^{37} \mathrm{O}$ Poder Judiciário passa a exercer o importante papel de controle das normas constitucionais como órgão suficientemente independente e imparcial, respeitados os titulares do poder político, assim como o papel do juiz toma proporções gigantescas, cabendo-lhe a responsabilidade de controlar a respeito da finalidade, limites e modalidades do agir do Estado. ${ }^{38}$

No Estado de Direito, o juizz está diretamente adstrito à constituição do seu país, sendo Que sua responsabilidade perante a sociedade decorre do compromisso com a preservação dos seus fundamentos. Isto, no entanto, não Quer dizer que o juiz no Estado Democrático possa sofrer perda de sua liberdade decisória. ${ }^{39}$

A atividade do juiz, portanto, de descoberta do direito, não é neutra, mas também não é discricionária. Deve ser adotada em função das regras e princípios implícitos e explícitos determinados pelo sistema, de tal sorte Que a decisão, ainda que inovadora, mantenha coerência com o ordenamento jurídico vigente, Que não perde por isso a sua identidade. ${ }^{40}$

\subsection{A Discricionarizdade do Administrador Público na Implantação das Políticas Públicas}

Primeiramente, cumpre esclarecer o Que sejam políticas públicas, aqui tratadas. Poder-se-ia defini-las como metas coletivas conscientes que direcionam a atividade do Estado. objetivando o interesse público. ${ }^{41}$ Ainda definindo políticas públicas, poder -se-ia dizer Que são uma espécie de padrão de conduta ("standard") Que assinala uma meta a alcançar, em

${ }^{36}$ CAPPELLETT1, Mauro. Constitucionalismo moderno e o papel do Poder ludiciário na sociedade contemporânea. Revista de Processo, São Paulo, v. 15, n. 60, p. 110-117, out./dez. 1990.

${ }^{37}$ CAPPELIETTI, Mauro. Constitucionalismo moderno e o papel do Poder Judiciário na sociedade contemporânea. Revista de Processo, São Paulo, v. 15, n. 60, p. 110-117, out./dez. 1990.

34 CAPPELLETTI, Mauro. Constitucionalismo moderno e o papel do poder judiciário na sociedade contemporânea. Revista de Processo, São Paulo, v. 15, n. 60, p. 110-117, out./dez. 1990.

39 AGUIAR lúNiOR. Ruy Rosado de. Responsabilidade política e social dos juízes nas democracias modernas. STJ - Dez anos a serviço da lustiça - Doutrina - Edição Comemorativa, Brasília, p. 323 347, 1999.

40 AGUIAR júNIOR, op. cit., p. 332-333.

41 GARCIA, Maria. Políticas Públicas e atividade administrativa do Estado. Revista dos Tribunais Cadernos de Direito Constitucional e Ciência Política, São Paulo, v. 4, n. 15, p. 64/67, abr./ jun. 1996. 
geral uma melhoria econômica, politica ou social da comunidade, podendo esta meta ser negativa no sentido de Que determinada característica deve ser protegida. ${ }^{42}$

Ao Administrador cabe implementar as políticas públicas discriminadas na ordem constitucional social, não havendo que se falar em discricionariedade para deliberar sobre a conveniência e oportunidade de sua implementação. Isto porQue tal já restou deliberado pelo Constituinte e pelo legislador infraconstitucional que elaborou as normas de integração. ${ }^{43}$ Nesse sentido, a Constituição deixa de ser vista como mera proclamação de intenções político-filosóficas e se afirma hoje como norma jurídica, vinculante e superior à lei ordinária. ${ }^{44}$

A própria legitimidade do Estado Social está ligada à realização de políticas públicas Que se caracterizam por todas as formas de intervenção do Estado, seja como provedor, gerenciador ou fiscalizador. ${ }^{45}$ É inadmissível que no atual estágio do Estado Social Qualeuer doutrina se recuse a dar força normativa aos preceitos Que fixam deveres positivos ao Estado e à sociedade no cumprimento dos objetivos sociais.

Ao operador do Direito incumbe a retirada da máxima eficácia e mais imediata aplicabilidade dessas normas, ainda Que vinculadas na forma de princípios programáticos. No mínimo essas normas vinculam a atividade legiferante, impondo ainda nítidos limites negativos à atuação estata!, Que não poderá desenvolver-se contrariamente ao definido pelo programa constitucional. ${ }^{46}$

O Administrador deverá levar em conta a razoabillidade, a proporcionalidade ${ }^{47}$ e a motivação na implementação de políticas públicas. Não é lícito ao administrador valorar situaçōes concretas à luz dos seus "standards" pessoais, mas sim à luz de princípios gerais, segundo os valores do homem médio. Ou seja, as decisões administrativas deverão estar atreladas à razoabilidade e às necessidades da coletividade, bem como à economicidade, isto é, à relação de custos e benefícios. ${ }^{48}$

42 COMPARATO, op. cit., p. 11-22.

43 FRISCHEISEN, Luiza Cristina Fonseca. Políticas públicas - A responsabilidade do Administrador e o Ministério Público. Săo Paulo: Max Limonad, 2000. p. 95.

4द CAPPELLETTII, Mauro. Constitucionalismo moderno e o papel do Poder Judiciário na sociedade contemporânea. Revista de Processo, São Paulo, v. 15, n. 60, p. 110/117, out./dez. 1990.

${ }^{45}$ GARCIA, op. cit., p. 64-67.

4h WEICHERT, op. cit.

47 Conforme BONAVIDES, Paulo.Curso de Direito Constitucional. São Paulo: Matheiros, 1994. p. 357, o princípio da proporcionalidade é: "A relaçăo entre fim e meio, confrontando o fim e o fundamento de uma intervenção com os efeitos desta para que se torne possivel um controle do excesso". Segue o autor, referindo que o princípio da proporcionalidade impöe a necessidade de equilíbrio entre o Legislativo e o Judiciário.

48 FIGUEIREDO. Lúcia Valle. O devido processo legal e a responsabilidade do Estado por dano decorrente do 
A motivação, por sua vez, apresenta-se como a pedra de toeue para o controle da discricionariedade na implantação das políticas públicas. Sem a motivação não há possibilidade de serem aferidas as razões utilizadas para a tomada de decisão do administrador, se baseadas em "standards" pessoais ou no que é Direito aqui e agora na comunidade. ${ }^{49}$

Segundo a teoria do "mobile politieue" da França do Segundo Império, por exemplo, os atos do governo seriam todos aqueles em relação aos Quais bastaria apenas o Executivo invocar, em tribunal, a "causa" ou "móbil" Que o havia inspirado, para que sua decisão fosse considerada insindicável. A teoria do "móbil político" havia declarado como insindicáveis determinados atos do Poder Executivo pela simples invocação de um motivo de oportunidade política. Tratava-se, portanto, de teoria de cunho subjetivista que estabefecia uma separação entre governo e jurisdição. ${ }^{50}$

A Constituição traduz os valores fundamentais, a idiossincrasia de um povo, o seu processo de vida em comum, sendo o texto escrito a sua garantia. Além disso, assegura a unidade do ordenamento jurídico, formado a partir de tensões e contradições e em meio a diferentes "verdades". Seus valores não são simples retórica sem valor normativo de aplicação, mas decisões políticas fundamentais. ${ }^{51}$

A Constituição Federal de 1988 traçou as diretivas e os princípios gerais das políticas públicas, decidindo pelo Estado Social, pela democracia, pelos direitos fundamentais, etc. Objetivou a construção de uma vida social e política como processo ordenado, conformado, previsivel nos seus momentos e aspectos fundamentais. ${ }^{52}$

Confunde-se "direção política" com "direção da política", sendo que aquela diz respeito às linhas constitucionais traçadas e esta, à atividade concretizadora pelo governo de tais linhas. No Estado de Direito a política pertence a um domínio constitucional, sendo que o Direito não substitui a política, mas serve de fundamento para esta tornando-a previsível e mensurável ao comum dos cidadãos. ${ }^{53}$

Se é certo Que não se inclui, ordinariamente, no âmbito das funções do Poder Judiciário a atribuição de formular e implantar políticas públicas, também é certo \&ue, embora em bases excepcionais. poderá o Judiciário assumir tal incumbência. Tal hipótese será possível se e Quando os órgãos estatais competentes descumprirem seus encargos políticos-jurídicos, comprometendo a eficácia dos direitos integrantes da ordem constitucional.

planejamento. Revista Trimestral de Direito Público, São Pauło, n. I1, p. 5-20, jul./set. 1995.

6) FIGUEIREDO, op. cit, p. 16/17.

so QUEIROZ, op. cit., p. 108-109.

5 QUEIROZ, op, cit., p. 138-139.

52 QUEIROZ, op. cit., p. 138-139.

53 QUEIROZ, op. cit., p. 138-139. 


\subsection{A Sindicabilidade Judicial das Políticas Públicas - Limites}

Um efetivo sistema de controle judicial mostra-se incompativel com regimes antilibertários e autocráticos, fato esse que pode ser confirmado pelo seu desenvolvimento em vários continentes, e mais freqüentemente na América Latina e África. Nesta, a título de ilustração, ocorreu uma crise constitucional em I950, justamente no momento em Que o Judiciário declarou inconstitucionais certas promulgaçōes do Parlamento Sul Africano. A crise culminou com a adoção da Constituição Sul Africana de I961, a Qual negava ao Judiciário Qualquer autoridade para revisar a validade dos atos legislativos. ${ }^{54}$

Ainda que discordemos e até lutemos contra determinadas decisões judiciais ou contra certos entendimentos judiciais em matéria constitucional, um século e meio de história continental está aí para demonstrar que solução alternativa é pior. Ou seja, na ausência de um controle judicial, facilita-se a Que o poder político seja pervertido, indo até mesmo contra a proteção de nossas liberdades. ${ }^{55}$

A lusticialidade ${ }^{56}$ está expressa no inciso XXXV do art. $5^{\circ}$ da Constituição Federal de 1988, o Qual estabelece Que: "A lei não excluirá da apreciação do Poder Judiciário lesão ou ameaça a direito". Este princípio foi explicitado pela primeira vez pela Constituição de 1946. no seu art. $141, \S 4^{\circ}$, Que, no entanto, não se referia à ameaça de lesão, sendo mais tarde previsto na Constituição de 1967 (art. 150, $4^{\circ}$ ) e na Emenda n. 1/69 (art. 153, $4^{\circ}$ ), a Qual procurou sujeitar essa garantia a um condicionamento. ${ }^{57}$

Deve ser afastada a clássica idéia de que o ludiciário não tem competência para julgar Questões políticas, tendo em vista o princípio da separação de poderes. Em nossa Constituiç̧ão de 1934, havia uma regra (art. 68) Que vedava ao Poder Judiciário conhecer de Questóes exclusivamente políticas. 5ignificava Que se negava o poder de julgar determinados atos, considerados discricionários, das Câmaras Legislativas ou de Chefes do Poder Executivo. Na verdade, tratava-se de pobre hermenêutica, uma vez Que tais atos não deveriam ficar imunes ao juízo de compatibilidade com as regras especificamente postas pela Constituição. ${ }^{58}$

Uma vez positivados os direitos sociais e suas garantias, o problema da judicialização de tais direitos não é de substituição do Executivo pelo Judiciário. Trata-se, isto sim, de cumprimento da Constituição e de interpretação das normas constitucionais e legais e ainda de observância aos limites da discricionariedade da administração. ${ }^{59}$

54 CAPELLETTI, Mauro. Repudiando Montesquieu? A Expansão e a Legitimidade da "Justiça Constitucional". Revista da Faculdade de Direito da Universidade Federal do Rio Grande do Sul, Porto Alegre, v. 20, p. 266, out. 2001.

55 CAPELLETT], Mauro. Repudiando Montesquieu? A Expansão e a Legitimidade da "lustiça Constitucional". Revista da Faculdade de Direito da Universidade Federal do Rio Grande do Sul, Porto Alegre, v. 20, p. 286, out. 2001.

${ }_{56}$ Conforme exposto no item 1.1.

57 FERREIRA FILHO, op. cit., p. 116.

58 COMPARATO, op. cit, p. 11-22.

59 FRISCHEISEN, op. cit., p. 95. 
Entre os que entendem Que o ludiciário não pode exigir o cumprimento de Políticas Públicas, sob pena de substituir-se ao administrador, e os Que entendem que o ludiciário tudo pode, é preciso encontrar um ponto de equilíbrio. Ao mesmo tempo que o juiz está comprometido com a efetividade da Constituiçã̃o, não pode, no entanto ultrapassar certos limites sob pena de colocar em risco certos postulados do Estado de Direito. O Que se discute, portanto, não é a possibilidade do controle judicial sobre as políticas públicas, mas a sua medida.

A intensidade do controle não depende do Tribunal, mas da Constituiçăo. A Constituição Federal de 1988 prevê, por exemplo, em seu art. 208 , inciso $\mathrm{I}^{60}$, o direito à educação, especialmente no Que concerne ao ensino fundamental, constituindo-se este em direito público subjetivo exigível pelo Poder fudiciário, Que, por sua vez, ordenará ao Poder Público as providências cabiveis para a sua concretização. ${ }^{61}$

Outro exemplo é o direito à saúde ${ }^{62}$, Que foi regulamentado pelo legislador infraconstitucional. Neste caso, a Constituição conferiu ao legislador uma margem substancial de autonomia na definição da forma e da medida em que o direito deve ser assegurado, o chamado "ívre espaço de conformação". Portanto, o Poder Judiciário, não poderá substituirse a outro Poder em juízos de conveniência e oportunidade, Querendo controlar as opçóes legislativas de prestação e organização a não ser Que haja uma violação evidente e arbitrária do legislador em relação a sua incumbência constitucional. ${ }^{63}$

Dessa forma, poder-se-ia dizer Que o Poder Judiciário age como delegado do Poder Constituinte. Nessa Qualidade, zela pela observância dos direitos fundamentais, protegendo a maioria permanente (constituinte) contra a maioria eventual, conjuntural e temporária (legislatura). ${ }^{64}$

Afirme-se, portanto, Que à luz da Constituição Federal de 1988, o legislador deverá sałisfazer os princípios, objetivos e direitos fundamentais esłabelecidos pelo Constituinte. Ao Judiciário, por sua vez, cabe a concretização das disposições constitucionais, $\mathrm{em}$ virtude da ação do Executivo, ao Qual incumbe desenvolver políticas públicas realizadoras de direitos. ${ }^{65}$

Impõe-se ao ludiciário Que assuma seu papel como instrumento de efetivação dos direitos previstos pelo constituinte dentro de determinados limites. Tais limites serão aqueles impostos pela ordem constitucional, especialmente os limites orçamentários, devendo atentar para o respeito aos recursos estatais disponíveis ${ }^{66}$.

\footnotetext{
60 "Art. 208: O dever do Estado com a educação será efetivado mediante a garantia de: 1 - ensino fundamental obrigatório e gratuito, assegurada, inclusive, sua oferta gratuita para todos os que a ele não tiveram acesso na idade própria."

6L CLÈVE, op. cit., p. 151-161.

62 Conforme relerido no item 1.2 .

${ }^{63}$ CLÈVE, op. Cit., p. 151-161.

${ }^{64}$ CLỀVE, op. cit., p. 151-161.

${ }^{65}$ CLÈVE, op. cit., p. 15 $1-161$.

${ }^{66}$ Conforme referido no item I.I.
} 


\section{CONCLUSĀo}

É tempo de concluir. O moderno estado social de direito pressupóe a idéia de um Direito não separado da sociedade e intimamente ligado às suas necessidades, suas demandas.

A Constituição Federal de 1988 garante o exercício do poder do Judiciário ao mesmo tempo em que o limita, buscando harmonizá-lo em relação ao exercício dos Poderes Administrativo e Legislativo.

Ao Poder Público, especialmente ao Poder Executivo, cumpre implementar as políticas públicas previamente deliberadas pelo constituinte e pelo legislador infraconstitucional, segundo critérios valorativos impostos por estes, independentemente de "standards" pessoais do Administrador.

A razoabilidade, a proporcionalidade e a motivação devem guiar o agir do Administrador Público na implantação das políticas públicas delineadas no ordenamento jurídico, a elas não podendo negar eficácia normativa, sob o argumento de não passarem de meras promessas sem um mínimo de eficácia vinculante do agir do Estado.

É preciso derrubar a idéia de violação ao princípio da separação de poderes, Quando o Judiciário exige do administrador a implementação de políticas públicas, adaptando o referido princípío à realidade de um Estado Social.

Mister se faz que o Judiciário assuma seu papel como instrumento de efetivação dos direitos previstos pelo constituinte, dentro dos limites impostos pela ordem constitucional, especialmente os limites orçamentários, respeitando os recursos estatais disponíveis.

Entretanto, a escassez de recursos com a Qual convive a sociedade brasileira não pode apresentar-se como óbice à implementação pelo Administrador, ainda Que progressiva, de políticas públicas. Por outro lado, deve ser reservado ao próprio Administrador o juízo de razoabilidade da exigência de determinado direito, assim como a ponderação das necessidades preeminentes da coletividade em contrapartida aos custos e benefícios na prestação do direito. Mais ainda, deve ser reservada ao Administrador a definição dos meios racionalmente possíveis e adequados para atingir o direito.

No Estado Social de Direito deve haver a reorganização da atividade estatal em função de suas finalidades coletivas, de modo Que o indivíduo seja atendido em suas demandas enQuanto integrante da sociedade.

É na Constituição Federal de 1988 e na ordem legal Que deve ser encontrado o fundamento para a exigibilidade da implantação das políticas públicas, não podendo o ludiciário refutar-se da nobre missão de zelar pelo respeito ao ordenamento jurídico, tampouco ultrapassar os exatos limites por este mesmo impostos. 
Nessa esteira, pode-se dizer, parafraseando Montesquieu, ${ }^{67}$ Que a medida do controle judicial das políticas públicas não é aquela que o juiz determinar, tampouco aquela que o poder público achar a mais conveniente ou oportuna, senão aquela descoberta pelo intérprete em sua atividade criativa, porém vinculada, ainda Que não mecânica ou inanimada, incrustada na ordem constitucional.

\section{REFERÊNCIAS BIBLIOGRÁFICAS}

BONAVIDES, Pauło. Curso de Direito Constitucional. 5. ed. São Paulo: Małheiros, 1994. CANOTLLHO, José Joaquim Gomes. Direito Constitucional. 5. ed. Coimbra: Almedina, 1992.

CAPPELLLETTI, Mauro. Constitucionalismo moderno e o papel do Poder ludiciário na sociedade contemporânea. Revista de Processo, São Paulo, v. 15, n. 60, p. 110-117, out./dez. 1990.

CAPPELLETTI, Mauro. Repudiando Montesquieu? A expansão e a legitimidade da "Justiça Constitucional". Revista da Faculdade de Direito da Universidade Federal do Rio Grande do Sul, Porto Alegre, vol. 20, p. 266, out. 2001.

CLÈVE, Clèmerson Merlin. A Eficácia dos Direitos Fundamentais Sociais. Boletim Cientíico ESMPU, Brasilia, ano 2, n. 8. p. 151-161, jul./set. 2003.

COMPARATO, Fábio Konder. Ensaio sobre o juízo de constitucionalidade de políticas públicas. Revista dos Tribunais, São Paulo, v. 86, n. 737, p. 11-22, mar. 1997.

DE AGUIAR IÚNIOR, RUY ROSADO. Responsabilidade política e social dos juízes nas democracias modernas. STI - Dez anos a serviço da lustiça - Doutrina - Edição comemorativa, Brasília, p. 323-347, 1999.

DOBROWOLSKI, Sílvio. A expansão do poder no Estado Social - Aspectos - Idéías para contê-la. Revista Forense, Rio de Janeiro, ano 82, v. 295, p. 145-154, jul./ago./set. 1986.

ENGELMANN, Fabiano. A "judicialização da política" e a "politização do ludiciário" no Brasil - Notas para uma abordagem sociológica. Revista da Faculdade de Direito da Universidade Federal do Rio Grande do Sul, Porto Alegre, vol. 22, p. 193-202, set. 2002.

FERREIRA FIL.HO, Manoel Gonçalves. O Estado de Direito e Constituição. 3. ed. São Paulo: Saraiva, 2004.

FIGUEIREDO, Lúcia Valle. O devido processo legal e a responsabilidade do Estado por dano decorrente do planejamento. Revista Trimestral de Diretto Público, São Paulo, n. 11, p. 520, jul./set. I995.

FRISCHEISEN, Luiza Cristina Fonseca. Políticas públicas. A responsabilidade do Administrador e o Ministério Público. São Paulo: Max Limonad, 2000.

GARCIA, Maria. Políticas públicas e atividade administrativa do Estado. Revista dos Tribunais - Cadernos de Direito Constitucional e Ciência Política, São Paulo, v. 4, n.15, p. 64-67, abr./jun. 1996.

MONTESQUIEU. Do espírito das teis. São Paulo: Martin Claret, 2002.

QUEIROZ, Cristina M. M. Os actos políticos no Estado de Direito - O problema do controie jurídico do poder. Coimbra: Almedina, 1990.

WEICHERT, Marlon Alberto. Saúde e federação na Constituição Brasileira. São Paulo: Lumen Juris, 2004.

${ }^{67}$ Conforme MONTESQuIEU.Do espírito das leis. São Paulo: Martin Claret, 2002, p. 172: "Os juízes da nação não são mais que a boca Que pronuncia as palavras da leí, seres inanimados que desta lei năo podem moderar nem a força nem o rigor". 